\title{
Development of Functional Cosmetic Material Using a Combination of Hippophae rhamnoides Fruit, Rubus fruticosus Leaf and Perillae folium Leaf Extracts
}

\author{
Ho Won Kim ${ }^{1}$, Dong-Sub Kim² ${ }^{2}$, Nak-Yun Sung ${ }^{2}$, In-Jun Han ${ }^{2}$, Byung Soo Lee ${ }^{2}$, Sang-Yun Park ${ }^{2}$, Ji Eom² ${ }^{2}$ Ji Young Suh ${ }^{2}$, Jihyun Park ${ }^{2}$, A-Reum \\ $\mathrm{Yu}^{1}$, Jong-Seok Kim ${ }^{1^{*}}$ \\ ${ }^{1}$ Myunggok Medical Research Institute, College of Medicine, Konyang University, Daejeon, Korea \\ ${ }^{2}$ Division of Natural Product Research, Korea Prime Pharmacy CO., LTD., Gwangju, Korea
}

\author{
*Corresponding author: Jong-Seok Kim, \\ Myunggok Medical Research Institute, \\ College of Medicine, Konyang University, \\ 158 Seogu Gwanjudongro Daejeon 35365, \\ Korea. \\ Tel.: +82426008648 \\ Fax: +82426008629 \\ Email: jskim7488@konyang.ac.kr
}

Ho Won Kim and Dong-Sub Kim contributed equally to this work.

Received October 10, 2019

Revised December 17, 2019

Accepted December 17, 2019

Published December 30, 2019

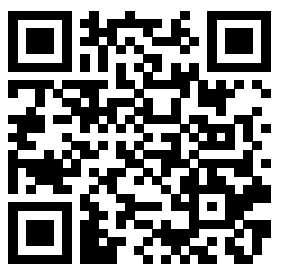

\begin{abstract}
Purpose: This study aimed to determine the optimal blending ratio of extracts of Hippophae rhamnoides (H. rhamnoides) fruit, Rubus fruticosus ( $R$. fruticosus) leaf, and Perillae folium ( $P$. folium) leaf as a potential functional material for antiwrinkle, antioxidant, anti-inflammatory, and whitening properties. Methods: We used the design of experiment (DOE) efficacy method to identify the optimal blend ratio for a natural extract complex. In addition, we tested the efficacy of the extract complex and the individual extracts by experiments, including elastase inhibition assay, NO inhibition assay, 2,2-diphenyl-1-picrylhydrazyl (DPPH) radical scavenging activity assay, tyrosinase inhibition assay, and ROS inhibition assay. Results: DOE methods using natural extracts showed that the most efficacious ratio of $H$. rhamnoides fruit: $R$. fruticosus leaf: $P$. folium leaf was 0.25:0.7:0.05. At this ratio, the elastase inhibitory effect, an indicator of wrinkle improvement, was $28 \%$ compared to the control. The antioxidant activity was $71.8 \%$ higher than the control. Additionally, NO formation was significantly suppressed by the extract complex. Tyrosinase inhibitory activity, a whitening index, showed $24.4 \%$ improvement over the control. Finally, hydrogen peroxide-induced cytotoxicity was significantly inhibited following treatment with the extract complex. Conclusion: The natural extract complex of $H$. rhamnoides, $R$. Fruticosus, and $P$. folium was found to have beneficial wrinkle improvement, antioxidant, anti-inflammatory, and whitening effects, and has potential as a functional cosmetic material.
\end{abstract}

Keywords: Hippophae rhamnoides fruit, Rubus fruticosus leaf, Perillae folium leaf, Wrinkle improvement, Whitening

\section{Introduction}

피부는 외부의 자극으로부터 신체를 보호하고 신체를 주위의 변화에 적응시키는 역할을 하며 기관 보호, 체온 조절, 감각, 분 비, 배설, 비타민D 합성, 표정, 재생 및 면역작용 등의 기능을 한 다. 이러한 피부는 나이가 들어감에 따라 노화가 진행되어 주름 이 생기고 탄력성을 잃어 가게 된다(Waller \& Maibach, 2006; Skobe et al., 2000). 노화는 우리몸의 구성기관 모두에서 나이 를 먹으며 일어난다. 피부 또한 나이를 먹으며 각질형성세포, 멜 라닌세포, 땀샘들의 기능이 저해되며 팽창력과 유연성을 잃으며
주름이 지고 탄력이 소실되어 간다. 이러한 현상을 생리적 노화 와 광노화로 설명하고 있다(Fisher et al., 2002). 생리적 노화에 는 피부의 구조와 생리적 기능이 나이를 먹으며 지속적인 감퇴를 일으키고 광노화는 장기간에 걸친 광선노출로 임상적 혹은 조직 적인 피부 변화를 일으키는 것을 말한다(Krutmann, 2012; Yaar $\&$ Gilchrest, 2001). 화장품은 피부의 주름을 감소시키고 노화 를 예방하기 위해 외부의 요인으로부터 보호하거나 생체 내 단백 질 합성을 촉진하여 노화현상을 지연시켜 탄력 있고 깨끗한 피부 를 유지하는 것을 목적으로 사용되어 왔다(Kang, 1997; Na et al., 2016). 많은 천연물 유래 생리활성물질들은 민간에서 오랫동 
안 약재로 사용하던 경우가 많았지만, 과학적인 입증은 매우 부족 한 편이다. 전세계 30 여만종의 식물 가운데 연구된 종은 $5 \%$ 남짓 의 적은 수밖에 되지 않는다. 최근 독성과 부작용이 기존 화합물 보다 적고 민간요법으로 사용되었던 유효성분을 포함한 천연물 유 래 화장품 개발이 활발해 지고 있다(Aburjai \& Natsheh, 2003; Masaki, 2010).

본 연구에서는 비타민 나무, 블랙베리, 약용들깨 추출물을 가 지고 각 기능성에 장점만을 모아 기능성 화장품 소재의 사용 가 능성을 확인하고자 하였다. 비타민나무(Hippophae rhamnoides L.)는 보리수과의 관목으로 산자나무로 불리기도 하며 오랜지색 열매를 맺고 내한성이 강한 식물이다(Lee, 2012). 잎과 열매에 는 비타민C, 비타민E등의 함량이 높으며 면역증진, 항염작용, 노 화 방지에 큰 효과를 내는 것으로 알려져 있다(Lee et al., 2018; Chauhan et al., 2004; Ganju et al., 2005). 블랙베리(Rubus fruticosus)는 쌍떡잎 식물 장미목 장미과 딸기속에 속하는 다년 생 식물로 비타민, 식이섬유 필수 미량요소와 무기질등이 풍부하 고 탄닌성분, 안토시아닌, 트리테르펜성분 등을 가지고 있어 항 암, 항알레르기, 항산화, 항비만, 항균등의 기능성을 나타낸다고 최근 많은 연구가 진행된 바 있다(Azofeifa et al., 2013; Cho et al., 2014), 약용들깨(Perillae folium)는 꿀풀과(Labiatae)에 속 하는 일년생 식물로 전체적으로 자색을 띄고 있고 잎자루가 길고 잎끝이 날카로운 것이 특징이며 최근까지 항염증, 항균, 항알레르 기, 항산화 활성에 대해 알려져 있다. 최근 많은 연구들을 통해 멜 라닌 생성 저해 및 미백효과가 있는 것으로 알려져 있다(Cho et al., 2019; Bak et al., 2011).

지금까지 알려진 비타민나무열매, 블랙베리잎, 약용들깨잎 추 출물들의 개별적 생리활성에 대한 연구가 되어 왔지만 이 추출물 들의 복합 기능성 생리활성에 대한 연구는 되어 있지 않다. 따라
서 본 연구는 비타민나무열매 추출물, 블랙베리잎 추출물, 약용들 깨잎 추출물을 이용한 복합 기능성을 갖는 배합비를 선정하여 기 능성 화장품 사용 가능성을 확인하기 위한 연구를 진행하였다.

\section{Materials \& Methods}

\section{1. 시료 및 추출}

구입한 천연 물질은 각각 $500 \mathrm{~g}$ 씩 용기에 담아 열에 의한 손상 을 피하기 위해 $60^{\circ} \mathrm{C}$ 에서 5 일 동안 건조하였다(Larrauri et al., 1997). 건조한 천연물질(비타민나무, 블랙베리, 약용들깨)은 분쇄 기(HM-2100S; Hanilelec, Korea)로 처리하여 50 mesh의 체를 통과한 미세입자를 선별하였다. 분쇄한 각각의 재료 $10 \mathrm{~g}$ 을 유리 병에 넣고 3차 증류수를 채워 최종적으로 $100 \mathrm{~mL}$ 가 되게 한 후 밀폐한 상태에서 $200 \mathrm{rpm}$ 으로 $30 \mathrm{~min}$ 동안 교반기(MSH-20A; Daihan, Korea)를 이용하여 현탁액을 만들고 $4{ }^{\circ} \mathrm{C}$ 의 냉장고에 넣 어 $48 \mathrm{~h}$ 동안 저온 숙성하였다. 이 후 원심분리기(UNION32R plus; Hanil Scientific, Korea)를 이용하여 $4^{\circ} \mathrm{C}$ 에서 5,000 rpm (원심력: $3000 \times \mathrm{g}$ )으로 $90 \mathrm{~min}$ 동안 침전물을 제거하고 투명한 상등액을 분리하였다. 각 재료의 추출물은 추가의 분획 과정 없이 분석대상 표준물질의 표준곡선 범위에 맞추어 희석하여 사용하였 다.

\section{2. 세포주 및 세포배양}

마우스 대식세포주인 RAW 264.7 세포와 사람의 피부 섬유 아세포(human dermal fibroblast)는 한국세포주은행(Korean Cell Line Bank, KCLB)에서 분양 받아 $10 \%$ fetal bovine serum (FBS; Gibco BRL, USA)과 1\% penicillin-streptomycin

\section{Table1. Experimental design and DOE results for optimal mixture ratio}

\begin{tabular}{cccc}
\hline No. & H. rhamnoides fruit & R. fruticosus leaf & \multicolumn{1}{c}{ P. folium leaf } \\
$\# 1$ & 1 & 0 & 0 \\
$\# 2$ & 0.75 & 0.25 & 0 \\
$\# 3$ & 0.75 & 0 & 0.25 \\
$\# 4$ & 0.5 & 0.5 & 0 \\
$\# 5$ & 0.5 & 0.25 & 0.25 \\
$\# 6$ & 0.5 & 0 & 0.5 \\
$\# 7$ & 0.25 & 0.75 & 0 \\
$\# 8$ & 0.25 & 0.5 & 0.25 \\
$\# 10$ & 0.25 & 0.25 & 0.5 \\
$\# 11$ & 0.25 & 0 & 0.75 \\
$\# 12$ & 0 & 1 & 0 \\
$\# 13$ & 0 & 0.75 & 0.25 \\
\#15 & 0 & 0.5 & 0.5 \\
\end{tabular}

DOE, design of experiment; H. rhamnoides, Hippophae rhamnoides; $R$. fruticosus, Rubus fruticosus; P. folium, Perillae folium. 

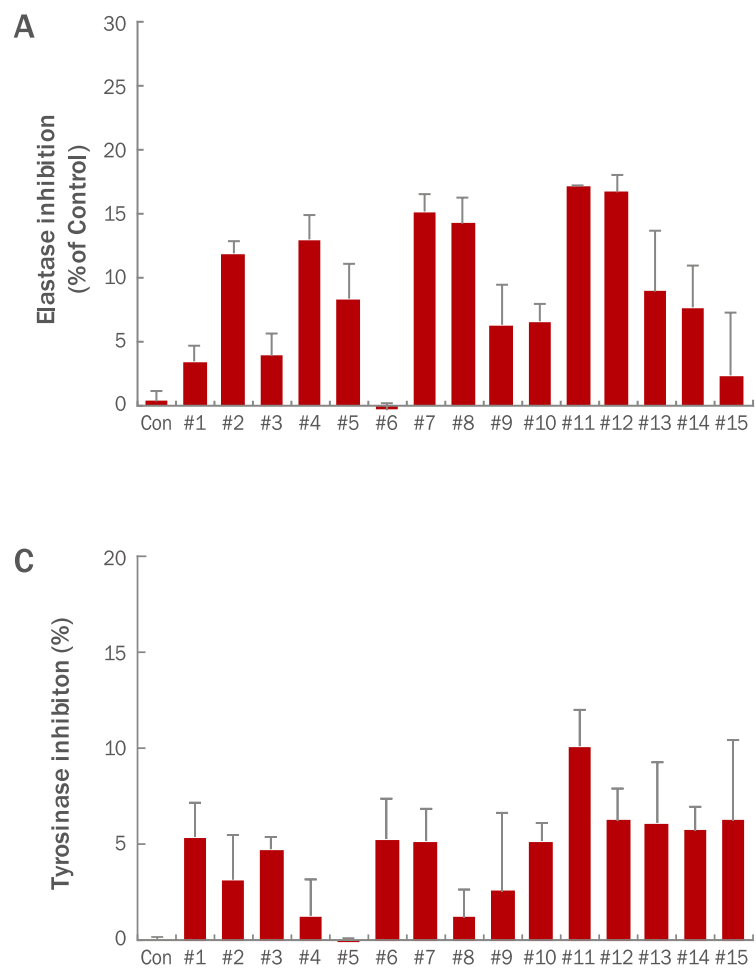

$E$

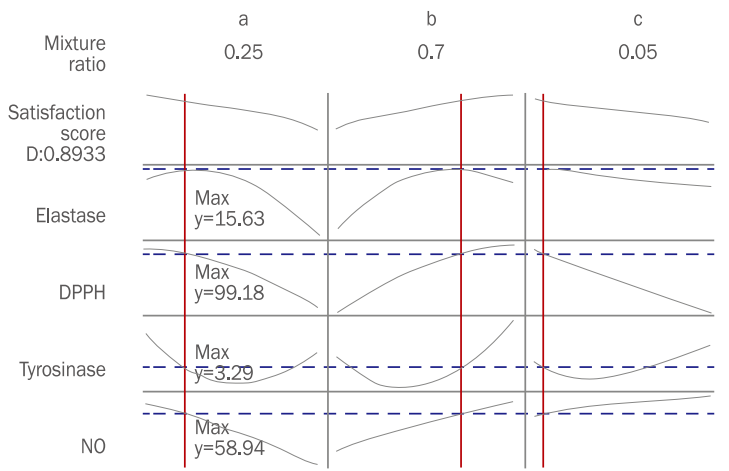

solution (P/S; Gibco BRL)을 첨가한 Dulbecco's Modified Eagle's Medium (DMEM; Gibco BRL)배지에 $37^{\circ} \mathrm{C}, 5 \% \mathrm{CO}_{2}$ 조 건에서 배양(MCO-20AIC; Sanyo, Japan)하였다. 세포 배양배 지는 세포가 $80 \%$ 이상 자란 시점에서 2-3일마다 교환하였다

\section{Design of experiment (DOE)를 이용한 최적배합비 설계}

비타민나무열매, 블랙베리잎, 약용들깨잎의 추출물은 3-(4, 5-dimethyl thiazol-2-yl)-2, 5-diphenyl tetra zolium bromide (MTT) assay를 통하여 세포독성이 나타나지 않는 농 도 내에서 실험계획에 사용하였고 선행연구에서의 $\mathrm{DPPH}$ 소거능, elastase 억제능, tyrosinase 억제능, NO 억제능 등을 개별적 효 능 농도 확인 후 미니탭(MINITAB ver. 18)을 사용하여 혼합물 설
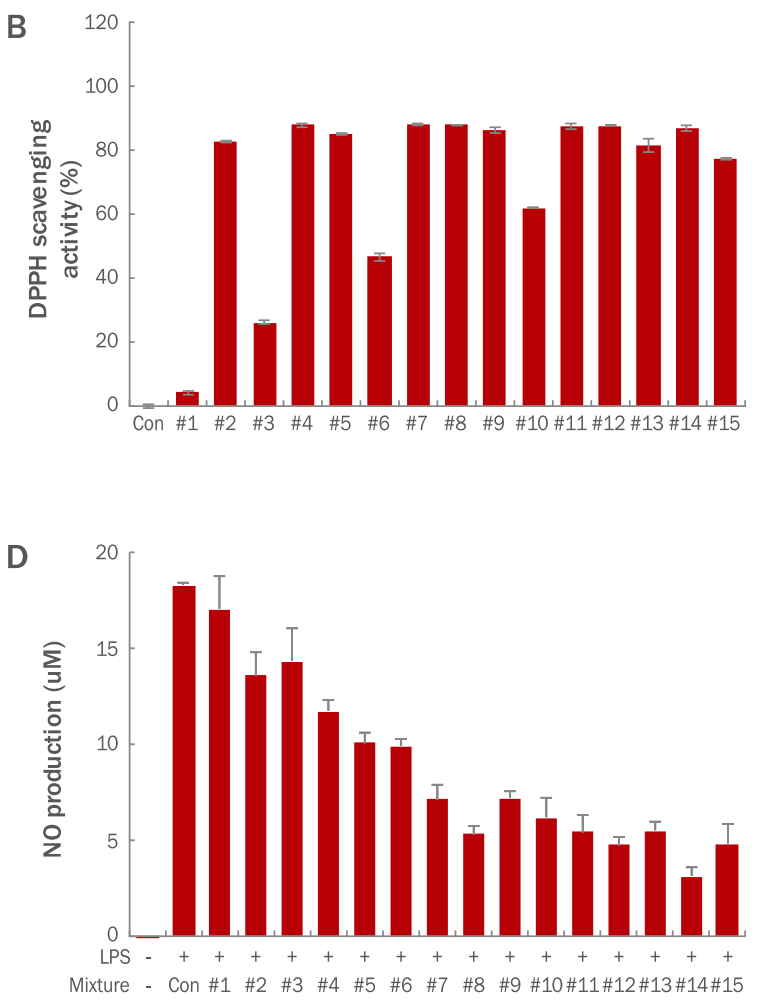

Figure 1. Screening results of natural products mixture ratio in functional effects.

(A) Elastase inhibition; (B) DPPH radical scavenging; (C) Tyrosinase inhibition; (D) NO production inhibition; (E) Confirmation of mixing ratio used DOE methods. The functional activity synthetic satisfaction of the final blend ratio was (a, 0.25; b, 0.7; c, 0.05). a, Hippophae rhamnoides fruit; b, Rubus fruticosus leaf; c, Perillae folium leaf; DOE, design of experiment. \#1-\#15, bath number for different ratios of $a, b$ and $c$; See Table 1 for detailed ratio information.

계(mixture design)에 따라 설계하여 최적의 배합비를 도출하여 실험에 적용하였다. 이때 시료의 성분비에 따라 혼합물 설계 중 심플렉스 중심 설계를 사용하였고 혼합물 총량을 1 로 두고 배합비 를 산정하였다.

\section{Elastase 억제 활성 측정}

천연추출복합물의 주름개선 효과를 평가하기 위해 elastase 활성 억제능을 확인하였다. 양성대조군 adenosine (SigmaAldrich, UK)을 사용하였으며 0.1 M Tris-HCl buffer (pH 8.0) 에 희석한 시료 $220 \mu \mathrm{L}$ 에 $2 \mathrm{mg} / \mathrm{mL} \mathrm{N}$-succinyl-Ala-AlaAla-p-nitroanilide (Sigma-Aldrich) $20 \mu \mathrm{L}$ 를 첨가하여 $25^{\circ} \mathrm{C}$ 조건에서 $20 \mathrm{~min}$ 반응시킨 다음, 얼음 위에서 반응을 종결시킨 
A

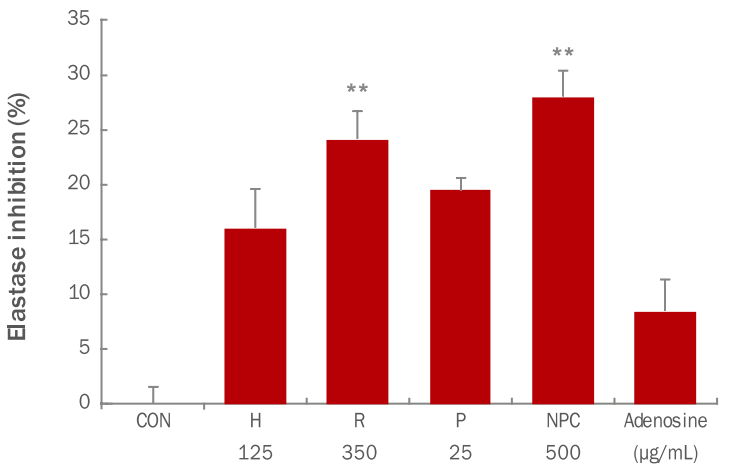

B

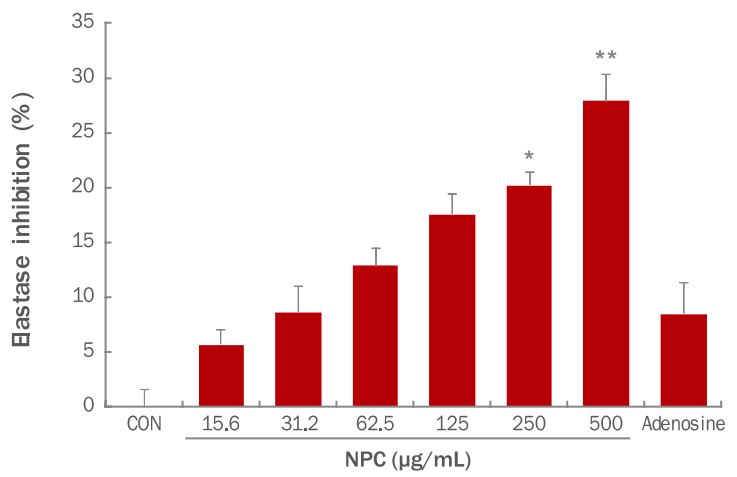

Figure 2. Inhibitory effects of natural products extract mixture at elastase.

Comparison of elastase inhibition effects of individual extracts and their mixtures (A) and for the treatment concentrations (B). The positive control was adenosine $(500 \mu \mathrm{g} / \mathrm{mL})$. Values are presented as mean \pm S.D. of the percentage of control optical density (experiments were performed in triplicates). Asterisks indicate significant differences $\left({ }^{*} p<0.05 ;{ }^{* *} p<0.01\right)$ between untreated control and treated extract by $t$-test. H, Hippophae rhamnoides fruit; R, Rubus fruticosus leaf; P, Perillae folium leaf; NPC, natural product-derived compound; S.D., standard deviation.
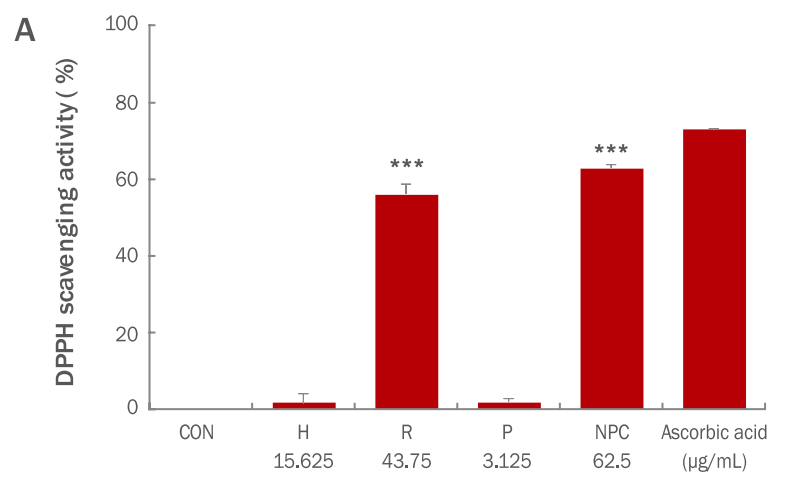

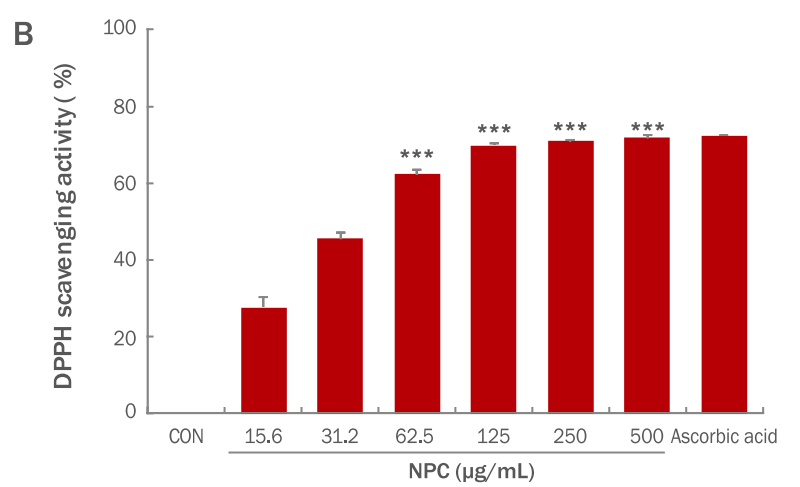

Figure 3. Antioxidative activities of natural products extract mixture.

Comparison of DPPH scavenging activity effect of extracts and mixtures (A) and for the treatment concentrations (B). The positive control was ascorbic acid $(500 \mu \mathrm{g} / \mathrm{mL})$. Values are presented as mean \pm S.D. of three independent experiments. Asterisks indicate significant differences ( ${ }^{* * *} p<0.001$ ). H, Hippophae rhamnoides fruit; R, Rubus fruticosus leaf; P, Perillae folium leaf; NPC, natural product-derived compound; DPPH, 2, 2-diphenyl-1-picrylhydrazyl; S.D., standard deviation.

후 microplate reader (SunriseTM; Tecan, Switzerland)를 이 용하여 $405 \mathrm{~nm}$ 에서 흡광도를 측정하였다(Moon et al., 2010).

\section{DPPH 라디칼 소거 활성}

천연추출복합물의 항산화 효과를 평가하기 위하여 1,1-diphenyl-2-picryl hydrazyl (DPPH; Sigma-Aldrich) 의 자유 라디칼 소거능을 확인하였다. 메탄올에 용해한 $200 \mu \mathrm{M}$ $\mathrm{DPPH} 200 \mu \mathrm{L}$ 에 희석한 시료를 $50 \mu \mathrm{L}$ 첨가하여 $37^{\circ} \mathrm{C}$ 에서 30 min 동안 반응시킨 후, microplate reader (Sunrise ${ }^{\mathrm{TM}}$ )를 이용하 여 $405 \mathrm{~nm}$ 에서 흡광도를 측정하였다. Ascorbic acid (SigmaAldrich)를 양성대조군으로 사용하였으며 천연추출복합물 처리군 와 무처리군의 흡광도 감소율로 나타내었다(Brand-Williams et al., 1995).

\section{Tyrosinase 억제 효과 측정}

천연추출복합물의 미백 효과를 평가하기 위하여 tyrosinase 활 성 억제능을 측정하였다. 0.1 M phosphate buffer (pH 6.5) 50 $\mu \mathrm{L}$ 에 시료 $50 \mu \mathrm{L}$ 와 $0.1 \mathrm{unit} / \mu \mathrm{L}$ tyrosinase (Sigma-Aldrich) $50 \mu \mathrm{L}$ 를 첨가하여 상온에서 $5 \mathrm{~min}$ 반응시켰다. $1 \mathrm{mM} \mathrm{L}-\mathrm{DOPA}$ $100 \mu \mathrm{L}$ 를 첨가 하여 $37^{\circ} \mathrm{C}$ 에서 $30 \mathrm{~min}$ 반응시킨 후 microplate reader (Sunrise $\mathrm{TM}^{\mathrm{TM}}$ 를 이용하여 $475 \mathrm{~nm}$ 에서 흡광도를 측정하였 다. Arbutin (Sigma-Aldrich)을 양성대조군으로 사용하였으며 tyrosinase 저해활성은 천연추출복합물 처리군와 무처리군의 흡 광도 감소율로 나타내었다(Sripathi et al., 2016). 
A

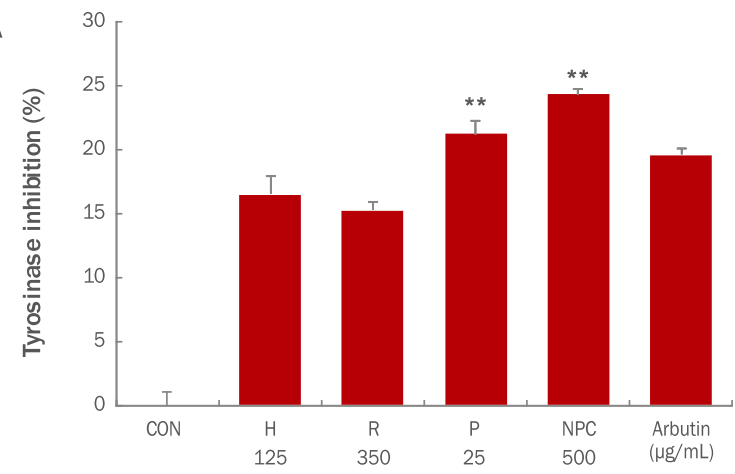

B

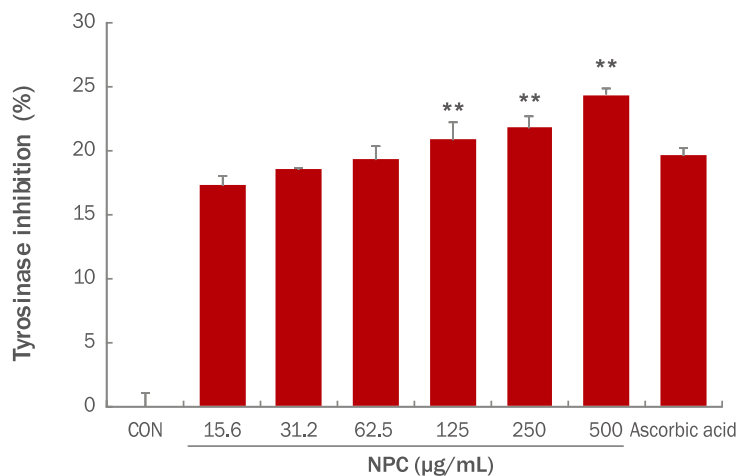

Figure 4. Tyrosinase inhibitory activities of natural products extract.

Comparison of tyrosinase inhibitory activity effects of extracts alone and in mixtures (A) and for the treatment concentrations (B). Arbutin was the positive control $(500 \mu \mathrm{g} / \mathrm{mL})$. Values are mean \pm S.D. of three determinations. Asterisks indicate significant differences ${ }^{*} p<0.05$; ${ }^{* *} p<0.01$ ) between untreated control and treated extract by $t$-test. H, Hippophae rhamnoides fruit; R, Rubus fruticosus leaf; P, Perillae folium leaf; NPC, natural product-derived compound; SD, standard deviation.

\section{NO 생성 억제능 측정}

천연추출복합물의 항염 효과를 평가하기 위하여 $\mathrm{NO}$ 생성 억 제능을 확인 하였다. 96 well plate에 RAW 264.7 세포(murine macrophages)를 $2 \times 10^{4}$ cells/well로 분주한 후 $37^{\circ} \mathrm{C}, 5 \% \mathrm{CO}_{2}$ incubator (MCO-20AIC; Sanyo, Japan)에서 $12 \mathrm{~h}$ 동안 배양 하면서 세포를 완전히 부착시키고, 시료 처리와 동시에 염증유 발 물질인 LPS (Sigma-Aldrich)를 $1 \mu \mathrm{g} / \mathrm{mL}$ 의 농도로 $24 \mathrm{~h}$ 동 안 병용 처리한 후 상층액을 분리하였다. 분리된 배양 상층액에서 $\mathrm{NO}$ 의 함량을 측정하였다. NO의 함량은 분리된 배양 상층액 100 $\mu \mathrm{L}$ 에 동량의 Griess (Sigma-Aldrich) 시약을 처리하여 $10 \mathrm{~min}$ 동안 반응시킨 후, microplate reader (Sunrise ${ }^{\mathrm{TM}}$ )를 이용하여 $517 \mathrm{~nm}$ 에서 흡광도를 측정하였다. 산화질소의 농도는 sodium nitrite $\left(\mathrm{NaNO}_{2}\right.$; Sigma-Aldrich)를 사용하여 얻은 표준직선과 비교하여 산출하였다.

\section{8. 활성산소종에 의한 세포 손상 보호 효과}

$\mathrm{ROS}$ 에 의한 산화적 스트레스로 인한 세포 손상을 줄일 수 있 는지 확인하기 위하여 $\mathrm{HDF}$ 세포를 96 well에 $2 \times 10^{4}$ cells/well 을 접종하고 $37^{\circ} \mathrm{C}, 5 \% \mathrm{CO}_{2}$ incubator (MCO-20AIC; Sanyo, Japan)에서 $12 \mathrm{~h}$ 동안 세포를 부착시켰다. 이 후 $\mathrm{H}_{2} \mathrm{O}_{2} 800 \mu \mathrm{M}$ 과 천연추출물 단일 및 복합물을 처리 하고 $24 \mathrm{~h}$ 후 Cell counting kit-8 (CCK-8) 법으로 세포의 활성도를 $490 \mathrm{~nm}$ microplate reader (Sunrise ${ }^{\mathrm{TM}}$ )에서 측정하였다.

\section{9. 활성산소종 생성 억제 효과}

산화적스트레스 억제효능을 보기 위해 6 well plate에 $18 \mathrm{~mm}$ cover glass 를 넣고 $2 \times 10^{5}$ cells/well을 접종한 후 DMEM/FBS $10 \%$ 배지와 함께 $5 \% \mathrm{CO}_{2}$ incubator (MCO-20AIC)에서 $12 \mathrm{~h}$ 동
안 배양하고 세포를 부착시켰다. 세포 부착을 확인 후 $\mathrm{H}_{2} \mathrm{O}_{2} 800$ $\mu \mathrm{M}$ 과 함께 복합 추출을 $250 \mu \mathrm{g} / \mathrm{mL}$ 처리하여 $6 \mathrm{~h}$ 동안 $5 \% \mathrm{CO}_{2}$ incubator에서 배양한 후 2',7'-dichlorofluorescin diacetate (DCF-DA; Invitrogen-Life Technology, US) $5 \mu \mathrm{M}$ 를 $30 \mathrm{~min}$ 암전에서 처리하였다. 이 후 mounting medium with DAPI (Vectashlide, US)로 염색한 후 형광현미경(Nikon, Japan)을 이 용하여 확인하였다.

\section{0. 통계처리}

본 연구의 모든 실험 결과는 동일 조건하에 독립적 3 회 이상 반복하여 평균값으로 나타내었고, 통계학적 유의성은 student's $t$-test로 분석하였으며, $p$ value가 0.05 미만일 경우 통계적으로 유의한 차이가 있는 것으로 나타내었다. ${ }^{*} p\langle 0.01)$.

\section{Results and Discussion}

\section{1. 실험계획법(DOE)를 이용한 최적 배합비}

실험계획법을 이용한 실험 설계를 위해 주름개선 지표 인 elastase 억제 효율, 항산화 지표인 DPPH, 미백의 지표인 tyrosinase 억제, 항염의 지표인 NO 생성 억제 효율을 스크리 닝 하였다. Table 1 과 같이 15 종의 배합 비율을 산정하여 각 효 율을 확인 하였다. Elastase의 억제 효율은 \#11번 배치에서 최대 약 $17.0 \%$ 를 나타냈으며 DPPH 라디칼 소거능은 \#4번 배치에서 $88.4 \%$ 의 최대 활성을 나타낸 것을 확인하였다. 또한 미백의 지표 인 tyrosinase 억제 효율은 최대 \#11번 배치에서 $9.0 \%$ 의 활성을 보였고 항염 활성은 \#14번에서 $3.1 \mu \mathrm{M}$ 로 줄여 $82.9 \%$ 의 최대 억 제 효율을 확인할 수 있었다(Figure $1 \mathrm{~A}-\mathrm{D}$ ). 각 억제효율을 바탕 
A

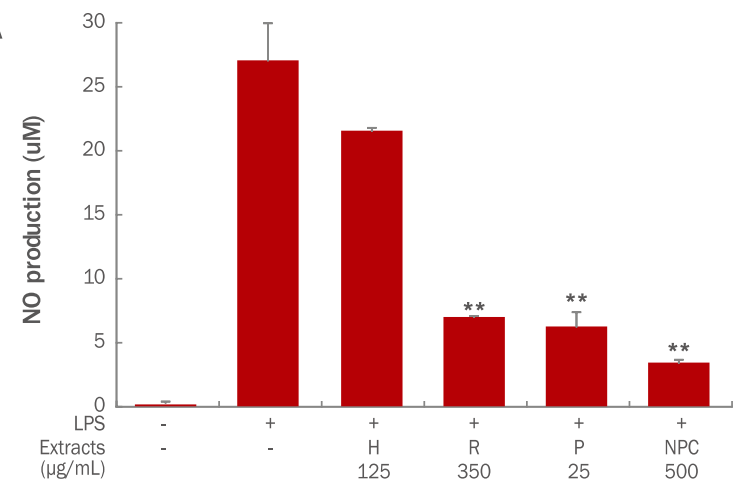

B

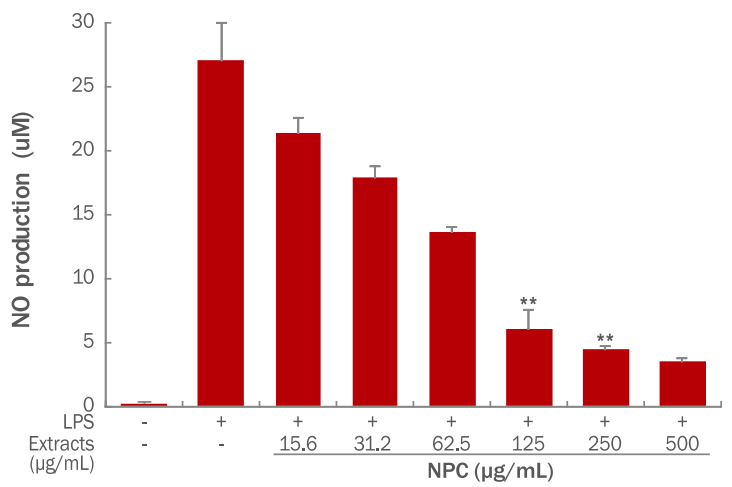

Figure 5. Effects of natural products extract mixture on NO synthesis in RAW 264.7 macrophage cells.

RAW 264.7 macrophage cells were treated for $24 \mathrm{~h}$ with natural product extracts and with LPS (1 $\mu \mathrm{g} / \mathrm{mL})$. Results show comparison between the LPS-only treated group and the experimental group treated with both LPS and natural product extract mixture. Values are presented as mean \pm S.D. of three independent experiments and statistical significance is shown. ${ }^{* *}$ means compared to LPS-treated condition ( $\left.{ }^{*} p<0.05 ;{ }^{* *} p<0.01\right)$. H, Hippophae rhamnoides fruit; R, Rubus fruticosus leaf; P, Perillae folium leaf; NPC, natural product-derived compound; NO, nitric oxide; LPS, lipopolysaccharides; S.D., standard deviation.

으로 $\mathrm{DOE}$ 를 통한 배합비율에 따른 최적의 배합비율을 설계하였 다. 종합 만족도는 1 기준에 0.8933 이였고 최대 근사치 값의 배합 비율은 비타민나무열매 $25 \%$, 블랙베리잎 $70 \%$, 약용들깨잎 $5 \%$ 의 최적 배합 비율로 계산되어 본 실험에 적용 하였다(Figure 1E).

\section{Elastase 억제 효과 측정}

Elastase 억제능은 피부노화의 척도로 사용되며 노화가 일어 날수록 elastase의 활성이 높아지는 것으로 알려져 있다(Baud et al., 2013). 본 연구에서는 천연추출복합물 처리군와 음성대 조군의 흡광도 감소율로 나타내었다. 각 단독추출물은 추출복합 물 $(500 \mu \mathrm{g} / \mathrm{mL})$ 의 비율 대비 농도로 처리 되었고 모든 처리군에 서 elastase 억제 효과가 있는 것으로 확인되었다. 비타민나무는 $16.0 \%$, 블랙베리는 $24.1 \%$, 약용들께는 $19.5 \%$ 의 억제 효율을 나 타내었다. 천연추출복합물은 이보다 높은 $28.0 \%$ 의 높은 억제 효 율을 보였고 이는 블랙베리 단독 처리군 보다 높은 수치이다. 또 한 양성대조군인 adenosine (8.4\%)보다 약 3 배 이상 높은 효율 을 보이는 것으로 통계적으로도 유의성 있는 결과로 확인되었다 (Figure 2A), 천연추출복합물의 농도별 억제 효능을 확인했을 때 농도의존적인 억제 효율을 확인할 수 있었다. 확인 농도 $250 \mu \mathrm{g} /$ $\mathrm{mL}$ 에서부터 음성대조군 대비 약 $20.2 \%$ 의 높은 억제 효율을 나타 내었다. 이는 양성대조군 $8.4 \%$ 보다 높은 수치로 통계적 유의성도 확인 되었다(Figure $2 \mathrm{~B})$. 이와 같이 천연추출복합물은 주름 개선 에 유의한 효과가 있는 것으로 판단 되었다.

\section{DPPH 자유 라디칼 소거능 측정}

천연물의 경우 라디칼 소거 활성은 체내 노화를 억제시키는 역
할을 하며 이 작용은 질병과 노화를 억제하는데 중요한 역할을 하 는 것을 알려져 있다(Assimopoulou et al., 2005). 각 단독추출 물은 추출복합물 $(62.5 \mu \mathrm{g} / \mathrm{mL})$ 의 비율 대비 농도로 처리 되었고 천연추출물 개별적 항산화 활성에서는 블랙베리의 라디칼 소거능 활성이 가장 큰 폭으로 증가 된 것을 확인할 수 있었으며 단독추 출물 대비 천연추출복합물에서 약 $6.7 \%$ 높은 라디칼 소거 활성을 보였다. 양성대조군인 ascorbic acid는 $72.4 \%$ 의 라디칼 소거능 을 보이고 천연추출복합물은 $62.4 \%$ 의 소거능이 나타났다(Figure $3 \mathrm{~A})$. 단독추출물의 최대 $\mathrm{DPPH}$ 라디칼 소거능은 $88.2 \%$ 였으나 (Figure 1B) DOE를 통한 최적설계에 의한 감소율이라고 사료된 다. 천연추출복합물은 $\mathrm{DPPH}$ 의 자유라디칼을 음성대조군 대비 $70.9 \%(250 \mu \mathrm{g} / \mathrm{mL})$ 의 소거 효율을 보였으며 양성대조군과 비슷 한 억제 효율인 것을 확인할 수 있었다(Figure $3 \mathrm{~B})$. 이 결과에서 최적 배합비 및 최적의 효능은 $62.5 \mu \mathrm{g} / \mathrm{mL}$ 실험군에서 가장 효 율성이 좋은 것으로 나타났고 $125 \mu \mathrm{g} / \mathrm{mL}$ 부터 양성대조군과 비 슷한 수치의 소거능을 보이는 것은 블랙베리의 배합비에 따른 비 율량의 효과라 사료된다(Wang et al., 2011). 따라서, 본 천연추 출복합물은 항산화 효과가 뛰어난 것으로 확인된다.

\section{Tyrosinase 활성 억제능 측정}

Tyrosinsase는 미백의 지표 마커로서 세포내 멜라닌 생성을 촉진하는 것으로 알려져 있고 억제할 경우 멜라닌의 생성이 억 제되어 미백의 활성이 나타나는 것으로 알려져 있다(Hearing, 2011). Tyrosinase 저해 활성능은 L-tyrosine이 기질로 작용하 여 tyrosinase에 의해 L-tyrosine이 L-DOPA로, L-DOPA 가 다시 L-DOPA quinone으로 전환되는 원리를 이용하였다(Hwang 
A

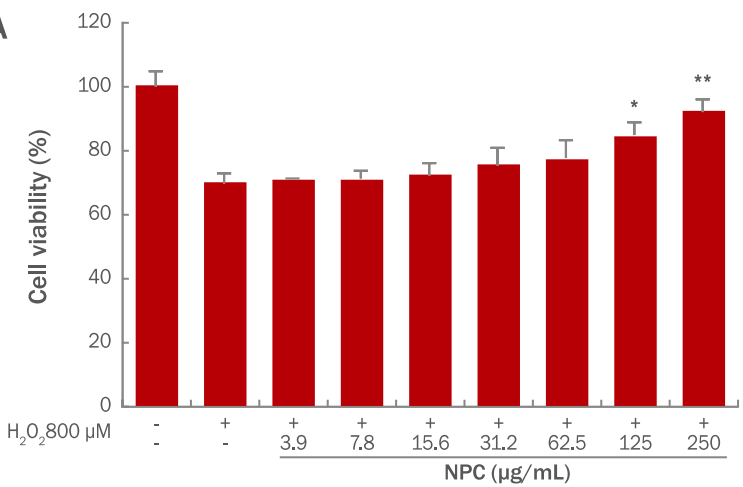

B

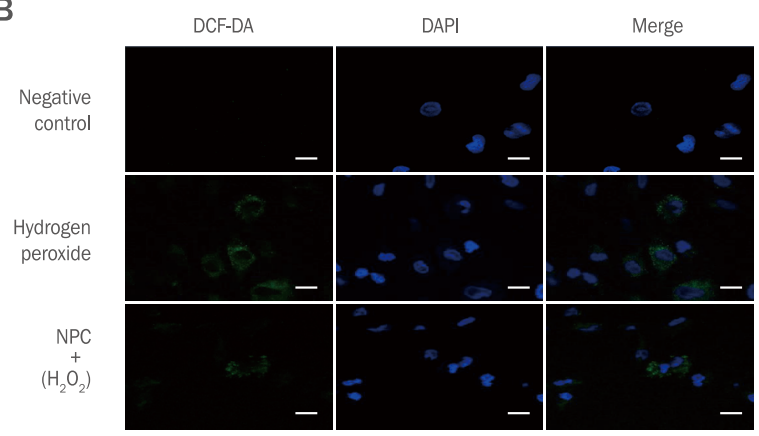

Figure 6. Protective effects of natural products extract in oxidative stress human dermal fibroblasts.

(A) Oxidative stress $\left(\mathrm{H}_{2} \mathrm{O}_{2}, 800 \mu \mathrm{M}\right)$ was applied to HDFs with and without natural product extracts in various concentrations $\left({ }^{*} p<0.05\right.$; ${ }^{* *} p<0.01$ ). (B) DCFDA staining of HDFs shows oxidative stress. Negative control, cells only; Hydrogen peroxide, $\mathrm{H}_{2} \mathrm{O}_{2}, 800 \mu \mathrm{M}$ (scale bar 100 um); NPC, natural product-derived compound; DCF-DA, 2',7'-dichlorofluorescin diacetate; DAPI, 4',6-diamidino-2-phenylindole.

et al., 2007). 각 단독추출물은 추출복합물 $(500 \mu \mathrm{g} / \mathrm{mL})$ 의 비 율 대비 농도로 처리 되었고 천연추출복합물의 처리군은 음성대 조군 대비 tyrosinase 활성 억제는 $24.4 \%$ 로 나타났고, 양성대조 군인 arbutin $(125 \mu \mathrm{g} / \mathrm{mL})$ 대비 천연추출복합물 $(125 \mu \mathrm{g} / \mathrm{mL})$ tyrosinase 활성 억제가 동일 농도 사용시 $5 \%$ 높게 나오는 것을 확인할 수 있었다(Figure 4A). 이는 통계적으로도 유의적인 결과 이며 비율에 따른 동일 농도 단독추출물 대비 복합추출물의 미백 활성이 높은 것을 확인할 수 있었다. 또한, 농도의존적으로 $15.6-$ $500 \mu \mathrm{g} / \mathrm{mL}$ 까지 억제 효능이 나타났으며 양성대조군과의 비교에 서 복합추출물 $62.5 \mu \mathrm{g} / \mathrm{mL}$ 에서 비슷한 수치의 효과가 나타나는 것을 확인할 수 있었다(Figure $4 \mathrm{~B})$. 따라서, 천연추출복합물은 미 백 효과에 유의한 효과가 있는 것으로 판단된다.

\section{NO 생성 억제능 측정}

세포 내 다양한 스트레스로 인한 $\mathrm{NO}$ 의 증가는 염증 반응의 하 나로 증가 될수록 피부 및 세포의 손상을 통한 노화를 유도하는 것으로 알려져 있다. 또한 작고 비교적 불안정하여 비특이적 독 성이 있는 분자로써 주로 숙주 면역계의 방어기전 등으로 잘 알려 져 있으며 피부의 UV-B 노출량에 따라 NO의 발생양도 많아지 는 것으로 알려져 있다(Cals-Grierson \& Ormerod, 2004). 천연 추출복합물의 염증의 지표인 NO 생성에 미치는 영향을 알아보기 위해 RAW 264.7 세포에 염증유발물질인 LPS $(1 \mu \mathrm{g} / \mathrm{mL})$ 를 처 리하여 염증을 유도하고 천연추출물을 처리 하였다. 항염증의 효 과는 비타민나무열매, 블랙베리잎, 약용들깨잎의 단독처리구에서 도 항염증의 효과가 높은 것을 확인할 수 있었다(Figure $5 \mathrm{~A}$ ). 천 연물의 단독처리 농도는 천연추출복합물의 비율 농도로 처리 되었 으며 천연추출물 무처리군에서 $27.1 \mu \mathrm{M}$ 의 $\mathrm{NO}$ 가 생성이 되었고 반면 비타민나무열매 $21.6 \mu \mathrm{M}$, 블랙베리잎 $6.9 \mu \mathrm{M}$, 약용들깨잎 $6.3 \mu \mathrm{M}$ 의 $\mathrm{NO}$ 생성을 확인할 수 있었다. 천연추출복합물에서는
단독추출물 비율 대비 $3.4 \mu \mathrm{M}$ 로 나타나 $\mathrm{NO}$ 생성 억제 효율이 가 장 높은 것으로 나타났다 $(p<0.01)$. 또한, 천연추출복합물은 125 $\mu \mathrm{g} / \mathrm{mL}$ 부터 NO 생성의 억제를 농도 의존적으로 줄였다 $(p<0.01$, Figure $5 \mathrm{~B})$. 천연추출복합물의 저농도인 $15.6 \mu \mathrm{M}$ 부터 고농도인 $500 \mu \mathrm{M}$ 까지 농도를 확인하였을 때 최대 억제효과는 $500 \mu \mathrm{M}$ 에서 나타났지만 효율 면에서는 $125 \mu \mathrm{M}$ 에서 가장 좋은 것으로 사료된 다. 따라서, 천연추출복합물은 항염 효과가 뛰어난 것으로 판단된 다.

\section{6. 활성산소종에 의한 세포 보호 효과}

활성산소종은 알려진 바와 같이 세포내 손상을 가해 세포의 수 명을 줄이거나 노화에 영향을 미치는 것으로 알려져 있다. 이를 줄이는 것이 세포손상과 노화를 억제하는데 도움이 될 수 있다고 알려져 있다(Masaki, 2010). 본 연구에서는 피부 노화와 관련이 있는 활성 산소종을 사람의 피부섬유세포인 $\mathrm{HDF}$ 세포에서 $\mathrm{H}_{2} \mathrm{O}_{2}$ 로 유도된 산화적 스트레스 모델을 사용하였다. 천연추출복합물 은 $125 \mu \mathrm{g} / \mathrm{mL}, 250 \mu \mathrm{g} / \mathrm{mL}$ 의 처리군에서 유의적인 세포의 보 호 효과를 나타내는 것으로 확인되었다(Figure $6 \mathrm{~A}$ ). 대조군인 $\mathrm{H}_{2} \mathrm{O}_{2}$ 만 처리군은 약 $69.7 \%$ 의 세포 생존율을 보인 반면 천연추출 복합물 처리군 $(250 \mu \mathrm{g} / \mathrm{mL})$ 에서는 약 $92.1 \%$ 의 생존율을 보여 약 $22.4 \%$ 의 유의적인 세포 성장율을 나타내었다. 이는 천연추출복합 물이 산화적 스트레스상태에서 세포의 손상을 줄여 세포 생존에 영향을 줄 수 있음을 확인할 수 있었다.

\section{7. 천연추출복합물의 활성산소종 생성 억제 효과}

천연추출복합물의 산화적스트레스 상태에서의 활성산소의 발 생과 억제를 확인한 결과 $250 \mu \mathrm{g} / \mathrm{mL}$ 을 처리한 군에서 대조군 대 비 활성산소의 발생이 적게 발생한 것을 확인할 수 있었다(Figure $6 \mathrm{~B})$. 천연추출복합물의 미처리군에서는 ROS의 생성이 많은 세포 
에서 다발성으로 발견되는데 반해 복합물 처리군에서는 전체적으 로 많은 양이 억제되는 차이를 보이는 것으로 확인되었다. 즉, 천 연추출복합물이 세포의 손상을 현저하게 감소시켜 세포의 생존에 중요한 역할을 하는 활성산소종을 억제하여 세포의 손상을 줄임으 로써 세포를 보호하는 효과라 할 수 있다. 이는 천연추출복합물이 세포내 산화스트레스를 줄여 세포를 보호 함으로써 세포 성장에 도움을 주는 것으로 판단된다.

\section{Conclusion}

본 연구는 천연추출복합물을 이용한 화장품 소재로의 가능성을 확인하기 위하여 $\mathrm{DOE}$ 를 통한 최적 배합비를 도출하여 elastase 억제와 항산화 및 항염 그리고 미백효과를 평가하였다. 비타민 나무열매 추출물, 블랙베리 잎 추출물, 약용들깨 잎 추출물 각각 의 활성을 바탕으로 최적배합비는 1 기준 $0.25: 0.7: 0.05$ 이였 다. 이에 따라 모든 실험에서의 농도는 천연추출복합물의 최적 비율 대비 농도로 진행되었다. 천연추출복합물은 주름의 지표인 elastase의 대조군 대비 $15.6 \mu \mathrm{g} / \mathrm{mL}$ 부터 $500 \mu \mathrm{g} / \mathrm{mL}$ 의 억제효 능이 나타났으며 기존 단독 처리군의 활성보다 높은 효능을 나타 내는 것으로 확인된다. 또한, 항산화 활성에서도 대조군 대비 높 은 활성을 나타났는데 블랙베리잎 단일추출물에서 나타나는 항산 화 활성의 수준 보다 높은 효능을 나타냈다. 이와 같은 결과는 개 별적 단독추출물에서의 항산화 효과의 복합적 결과로 판단된다. 미백의 지표인 tyrosinase 억제도 천연추출복합물이 단독추출물 처리군 보다 높은 억제 효율을 나타내었다. 또한, 양성대조군보다 도 높은 미백활성도를 나타내었다. 천연추출복합물의 $15.6 \mu \mathrm{g} /$ $\mathrm{mL}$ 의 농도에서부터 음성 대조군 대비 $19.2 \%$ 의 높은 tyrosinase 억제 활성이 나타나는 것으로 확인 되었다. 천연추출복합물은 마 우스의 대식세포인 RAW 264.7세포주에서 LPS로 유도된 염증반 응에 농도의존적으로 $\mathrm{NO}$ 의 양을 줄이는 것을 확인할 수 있었다. 이 또한 단독 동일 농도 처리군 보다 높은 수준의 효능을 보여 각 추출물의 복합적 효과라 볼 수 있다. 사람의 피부섬유세포인 $\mathrm{HDF}$ 세포를 이용한 산화적스트레스에 ROS 생성과 억제를 확인한 결 과에서도 천연추출복합물 처리군의 세포 성장이 높아져 천연추출 복합물에 의한 세포 증식 효과를 확인 할 수 있었다. 또한, 천연복 합추출물을 처리한 군에서는 대조군 대비 적은양의 ROS가 생성 됨을 확인할 수 있었다. 이는 세포내 ROS 생성을 줄여 세포 성장 과 증식에 도움을 주고 세포 보호 효과로 나타나는 것으로 사료된 다. 이는 타 선행연구와 같은 결과라 이야기 할 수 있고(Maurya et al., 2009), 다양한 생리활성 물질의 효능이 가중되어 단독사용 보다는 천연추출복합물 사용으로 인한 상승효과로 판단된다.

본 연구결과는 세포수준에서의 실험으로 진행되었고 화장품 소 재활용을 위한 피부 적용 시 목적 효과를 나타낼 가능성이 있는지
를 향후 연구가 추가되어야 할 것으로 생각되며 비타민나무열매, 블랙베리잎, 약용들깨잎의 천연추출복합물은 주름개선, 항산화, 항염, 미백에 효능을 가지는 복합 기능성 화장품 소재로 활용이 가능할 것으로 사료된다.

\section{Acknowledgements}

이 논문은 2017년도 정부(교육부)의 재원으로 한국연구재단의 대학중점연구소 지원사업(NRF-2017R1A6A1A03015713) 및 2018년도 정부(과학기술정보통신부)의 재원으로 한국연구재단의 신진연구지원사업(NRF-2018R1C1B6007421)으로 수행된 연구 임.

\section{Author's contribution}

HWK and DSK contributed equally to this work. HWK and DSK designed all experimental investigations, and developed the process for analyzed data, and wrote the manuscript. JE, JYS, JP, IJH, and ARY performed natural products extraction and enzymatic experiments. NYS, BSL and SYP performed cell experiments. JSK make a check on a final manuscript.

\section{Author details}

Ho Won Kim (Graduate student), Myunggok Medical Research Institute, College of Medicine, Konyang University, 158, Gwanjeodong-ro, Seo-gu, Daejeon 35365, Korea; Dong-Sub Kim (Division Direction), Division of Natural Product Research, Korea Prime Pharmacy CO., LTD., 211, Jungang-ro, Dong-gu, Jeonnam 61473, Korea; Nak-Yun Sung (General Manager), Division of Natural Product Research, Korea Prime Pharmacy CO., LTD., 211, Jungang-ro, Dong-gu, Jeonnam 61473, Korea; InJun Han (Deputy General Manager), Division of Natural Product Research, Korea Prime Pharmacy CO., LTD., 211, Jungang-ro, Dong-gu, Jeonnam 61473, Korea; Byung Soo Lee (Manager), Division of Natural Product Research, Korea Prime Pharmacy CO., LTD., 211, Jungang-ro, Dong-gu, Jeonnam 61473, Korea; Sang-Yun Park (Manager), Division of Natural Product Research, Korea Prime Pharmacy CO., LTD., 211, Jungang-ro, Dong-gu, Jeonnam 61473, Korea; Ji Eom (Assistant Manager), Division of Natural Product Research, Korea Prime Pharmacy CO., LTD., 211, Jungang-ro, Dong-gu, Jeonnam 61473, Korea; Ji Young Suh (Staff), Division of Natural Product Research, Korea Prime Pharmacy CO., LTD., 211, Jungang-ro, Dong- 
gu, Jeonnam 61473, Korea; Jihyun Park (Staff), Division of Natural Product Research, Korea Prime Pharmacy CO., LTD., 211, Jungang-ro, Dong-gu, Jeonnam 61473, Korea; A-Reum Yu (Researcher), Myunggok Medical Research Institute, College of Medicine, Konyang University, 158, Gwanjeodong-ro, Seo-gu, Daejeon 35365, Korea; JongSeok Kim (Professor), Myunggok Medical Research Institute, College of Medicine, Konyang University, 158, Gwanjeodong-ro, Seo-gu, Daejeon 35365, Korea.

\section{References}

Aburjai T, Natsheh FM. Plants used in cosmetics. Phytotherapy Research, 17: 987-1000, 2003.

Assimopoulou AN, Sinakos Z, Papageorgiou VP. Radical scavenging activity of Crocus sativus L. extract and its bioactive constituents. Phytotherapy Research, 19: 9971000, 2005.

Azofeifa G, Quesada S, Boudard F, Morena M, Cristol JP, Pérez AM, Vaillant F, Michel A. Antioxidant and antiinflammatory in vitro activities of phenolic compounds from tropical highland blackberry (Rubus adenotrichos). Journal of Agriculture and Food Chemistry, 61: 57985804, 2013.

Bak JP, Kim JB, Park JH, Yang YJ, Kim IS, Choung ES, Kang SC. Screening and compound isolation from natural plants for anti-allergic activity. Journal of the Korean Society for Applied Biological Chemistry, 54: 367-375, 2011.

Baud S, Duca L, Bochicchio B, Brassart B, Belloy N, Pepe A, Dauchez, M, Martiny L, Debelle L. Elastin peptides in aging and pathological conditions. Biomolecular Concepts, 4: 65-76, 2013.

Brand-Williams W, Cuvelier ME, Berset C. Use of a free radical method to evaluate antioxidant activity. $L W T$ Food Science and Technology, 28: 25-30, 1995.

Cals-Grierson MM, Ormerod AD. Nitric oxide function in the skin. Nitric Oxide, 10: 179-193, 2004.

Chauhan AS, Negi PS, Ramteke RS. Antioxidant and antibacterial activities of aqueous extract of Seabuckthorn (Hippophae rhamnoides) seeds. Fitoterapia, 78: 7-8, 2007.

Cho BO, Lee CW, So Yk, Jin CH, Yook HS, Byun MW, Jeong
YW, Park JC, Jeong IY. Protective effects of radiationinduced blackberry mutant extract on carbon tetrachloride ( $\mathrm{CCl} 4)$-induced liver injury in spraguedawley rats. Journal of the Korean Society of Food Science and Nutrition, 43: 807-813, 2014.

Cho EJ, Byun EH. Antimelanogenic effect and whitening of crude polysaccharide fraction extracted from Perilla frutescens Britton var. acuta Kudo. Korean Journal of Food Science and Technology, 51: 58-63, 2019.

Fisher GJ, Kang S, Varani J, Bata-Csorgo Z, Wan Y, Datta $\mathrm{S}$, Voorhees JJ. Mechanisms of photoaging and chronological skin aging. Archives of Dermatology, 138: 1462-1470, 2002.

Ganju L, Padwad Y, Singh R,Karan D, Chanda S, Chopra MK, Bhatnagar P, Kashyap R, Sawhney RC. Anti-inflammatory activity of Seabuckthorn (Hippophae rhamnoides) leaves. International Immunopharmacology, 5: 16751684, 2005.

Hearing VJ. Determination of melanin synthetic pathways. Journal of Investigative Dermatology, 131: E8-E11, 2011.

Hwang $\mathrm{JH}$, Lee BM. Inhibitory effects of plant extracts on tyrosinase, L-DOPA oxidation, and melanin synthesis. Journal of Toxicology and Environmental Health, 70: 393-407, 2007.

Kang $\mathrm{HH}$. Anti-aging in cosmetics. Journal of the Society of Cosmetic Scientists of Korea, 23: 57-74, 1997.

Krutmann J, Morita A, Chung JH. Sun exposure: what molecular photodermatology tells us about its good and bad sides. Journal of Investigative Dermatology, 132: 976-984, 2012.

Larrauri JA, Rupérez P, Saura-Calixto F. Effect of drying temperature on the stability of polyphenols and antioxidant activity of red grape pomace peels. Journal of Agricultural and Food Chemistry, 45: 1390-1393, 1997.

Lee HK. Antioxidant and anti-wrinkle effects of quercetin 3-glucoside-7-rhamnoside isolated from Hippophae rhamnoides fruits. Asian Journal of Beauty and Cosmetology, 10: 731-736, 2012.

Lee SY, Shon JY, Kang KO. Nutritional components and antioxidant activities of sea buckthron (Hippophae rhamnoides L.) leaf and berry extracts. Journal of the East Asian Society of Dietary Life, 28: 31-39, 2018. 
Masaki H. Role of antioxidants in the skin: anti-aging effects. Journal of Dermatological Science, 58: 85-90, 2010.

Maurya PK, Rizvi SI. Protective role of tea catechins on erythrocytes subjected to oxidative stress during human aging. Natural Product Research, 23: 1072-1079, 2009.

Moon JY, Yim EY, Song G, Lee NH, Hyun CG. Screening of elastase and tyrosinase inhibitory activity from Jeju Island plants. EurAsian Journal of BioSciences, 4: 4153, 2010.

$\mathrm{Na}$ EJ, Jang HH, Kim GR. Review of recent studies and research analysis for anti-oxidant and anti-aging materials. Asian Journal of Beauty and Cosmetology, 14: 481-491, 2016.

Skobe M, Detmar D. Structure, function, and molecular control of the skin lymphatic system. Journal of Investigative Dermatology Symposium Proceedings, 5:
14-19, 2000.

Sripathi SK, Lalitha P. Keratolytic molecule aided inhibition of DNA damage and tyrosinase activity of a herbal formulation. International Journal of BioSciences and Technology, 9:7, 2016.

Waller JM, Maibach HI. Age and skin structure and function, a quantitative approach (II): protein, glycosaminoglycan, water, and lipid content and structure. Skin Research and Technology, 12: 145-154, 2006.

Wang S, Meckling KA, Marcone MF, Kakuda Y, Tsao R. Synergistic, additive, and antagonistic effects of food mixtures on total antioxidant capacities. Journal of Agricultural and Food Chemistry, 59: 960-968, 2011.

Yaar M, Gilchrest BA. Skin aging: postulated mechanisms and consequent changes in structure and function. Clinics in geriatric medicine, 17: 617-630, 2001. 


\section{국문초록}

\section{비타민나무열매, 블랙베리잎과 약용들깨잎의 추출물 복합제를 이용한 복합 기능성 화 장품 소재 개발}

김호원 ${ }^{1}$, 김동섭 ${ }^{2}$, 성낙윤 $^{2}$, 한인준 ${ }^{2}$, 이병수 ${ }^{2}$, 박상윤 $^{2}$, 엄지 $^{2}$, 서지영 ${ }^{2}$, 박지현 $^{2}$, 유아름 ${ }^{1}$, 김종석 ${ }^{1 *}$

${ }^{1}$ 건양대학교 의과대학 명곡의학연구소, 대전시, 한국

2한국프라임제약 천연물연구부, 광주, 한국

목적: 본 연구는 천연추출복합물을 이용한 기능성 화장품 소재개발을 위한 효력시험을 통해 검증하고자 한다. 방법: 천연추출복 합물의 개별적인 elasterase 억제능, DPPH 라디칼 소거능, nitric oxide 억제능, tyrosinase 억제능, ROS 생성 억제능을 측정하여 design of experiment (DOE)를 통한 최적의 배합비를 찾고 최종 배합비에 따른 효능을 확인 하였다. 결과: 천연추출복합물을 이용 한 DOE는 각 천연물의 효능을 극대화 하여 최적의 배합비를 예측했을 때 비타민나무열매:블랙베리잎:약용들깨잎(0.25:0.7:0.05) 의 배합비에서 최적의 효능을 나타냈다. 도출된 배합비를 바탕으로 주름개선의 지표인 elesterase 억제 효능을 확인하였을 때 음성 대조군 대비 $28 \%(500 \mu \mathrm{g} / \mathrm{mL})$ 의 억제 효과를 나타내었다. 항산화 지표인 2,2-diphenyl-1-picrylhydrazyl (DPPH) 라디칼 소거능 도 음성 대조군 대비 $71.8 \%$ 의 활성 효능을 나타내었다. 또한 염증 모델인 RAW 264.7세포에 lipopolysaccharides (LPS) 로 유도된 nitric oxide(NO)의 억제 효능도 대조구 대비 87.1\%의 활성을 나타내었고 미백 지표인 tyrosinase 억제 효능도 대조군 대비 $24.4 \%$ 의 효과를 확인하였다. 활성 산소종에 의한 세포 보호 효능을 알아 보기 위한 human dermal fibroblast (HDF) 세포에 hydrogen peroxide $\left(\mathrm{H}_{2} \mathrm{O}_{2}\right)$ 로 reactive oxygen species (ROS)를 유도한 모델에서도 유의적인 활성 산소종의 억제 효능을 나타내었다. 결론: 비 타민나무열매, 블랙베리잎, 약용들깨잎의 천연 추출 복합물은 주름개선과 항산화 항염과 미백에 효과가 있는 것으로 확인되어 기능 성 화장품 소재로의 개발이 가능한 것으로 사료된다.

핵심어: 비타민나무열매, 블랙베리잎, 약용들깨잎, 주름개선, 미백

이 논문은 2017년도 정부(교육부)의 재원으로 한국연구재단의 대학중점연구소 지원사업(NRF-2017R1A6A1A03015713) 및 2018년도 정부(과학기술정보통신부)의 재원으로 한국연구재단의 신진연구지원사업(NRF-2018R1C1B6007421)으로 수 행된 연구임.

\section{참고문헌}

김기호, 고강일, 강은정, 양은경, 박수남. 웰빙산업에서의 천연물 연구 동향. 대한화장품학회지, 30: 329-343, 2004. 강학희. 화장품과 피부노화. 대한화장품학회지, $23: 57-74,1997$.

나은주, 장현희, 김규리. 자연유래 항산화 원료와 제품개발을 위한 항산화 및 항노화 연구의 최신동향. 아시안뷰티화장품

학술지, 14: 481-491, 2016.

이소영, 손종연, 강근옥. 비타민나무 잎 및 열매의 영양성분과 추출물의 항산화 활성. 동아시아식생활학회지, $28: 31-39$, 2018.

이희경. 비타민나무 열매로부터 분리한 Quercetin 3-glucoside-7-rhamnoside의 항산화 및 주름개선 효과. 아시안뷰티 화장품학술지, 10: 731-736, 2012.

조병옥, 이창욱, 소양강, 육홍선, 변명우, 정용욱, 박종천, 정일윤. 방사선 돌연변이 블랙베리 추출물의 사염화탄소 투여에 의한 흰쥐의 간 손상에 대한 보호 효과. 한국식품영양과학회지, 43: 807-813, 2014.

조은지, 변의홍. 자소엽 조다당의 멜라닌 생성 저해 및 미백효과. 한국식품과학회지, 51: 58-63, 2019. 


\section{中文摘要}

\section{沙棘果实, 悬钩子叶和紫苏叶提取物组合开发功能性化妆品材料}

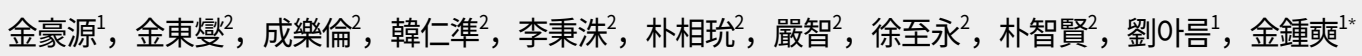

${ }^{1}$ 建阳大学医科大学Myunggok研究所, 大田市, 韩国

${ }^{2}$ Korea Prime Pharm有限公司天然物研究所, 光州, 韩国

目的: 探索作为抗皱, 抗氧化, 消炎和增白特性的潜在功能材料, 确定沙棘果实, 悬钩子叶和紫苏叶的提取物 的最佳混合比例。方法: 利用实验设计（DOE）功效方法来确定天然提取物复合物的最佳混合比例。此外，通 过实验测试了提取物复合物和单个提取物的功效, 包括弹性蛋白酶抑制测定, NO抑制测定, 2,2-diphenyl-1picrylhydrazyl (DPPH) 自由基清除活性测定, 酪氨酸酶抑制测定和ROS抑制试验。结果: 使用天然提取物的 DOE方法显示, 沙棘果实：悬钩子叶：紫苏叶的最有效比例为 $0.25: 0.7: 0.05$ 。在该比例下, 与对照群相比, 作为波纹改善指标的弹性蛋白酶抑制效果为 $28 \%$ 。抗氧化剂活性比对照群高 $71.8 \%$ 。另外, 提取物复合物显着 抑制了NO的形成。酪氨酸酶抑制活性（增白指数）显示比对照群提高 $24.4 \%$ 。最后，用提取物复合物处理后， 过氧化氢诱导的细胞毒性被显着抑制。结论: 沙棘果实, 悬钩子叶和紫苏叶的天然提取物复合物具有有盁的皱纹 改善, 抗氧化, 消炎和增白作用, 并具有作为功能性化妆品的潜力。

关键词: 沙束果, 悬钩子叶, 紫苏叶, 改善波纹, 美白 